\title{
Italian Center-Right Parties and Immigra- tion: A Political Patronage Approach
} Tommaso Pavone Gerald R. Ford School of Public Policy, tpavone@umich.edu

\author{
Professor Kenneth Kollman
}

Department of Political Studies and the International Institute

Summary of paper prepared for the University of Michigan's Undergraduate Research Journal

OVERVIEW AND THE CENTER-RIGHT'S IMMIGRATION RHETORIC-POLICY DIVIDE

The immigration issue has caustic in the Italian arena and is one of the most salient issues for Italian voters. The Italian electorate is more xenophobic than most of its European counterparts. A 2003 German Marshall Fund survey found that $78 \%$ of Italians surveyed believed immigrants constituted an 'extremely important' or 'important' threat to Europe in the near future. A survey ${ }^{1}$ conducted by the International Herald Tribune in May of 2007 found that $55 \%$ of Italians believe there are too many legal immigrants in Italy. This statistic is significantly higher compared with bordering nations. When asked how they believe the illegal immigrant situation should be remedied, a stunning $60 \%$ of Italians believe all illegal immigrants should be expelled. This percentage is the highest of any European nation surveyed.

Italian center-right parties are especially

1 The data was gathered using the statistical polling database, Polling the Nations. impacted by the immigration issue; center-right parties are seen as the most obvious advocates for more repressive immigration policies. There are four major parties of interest to this analysis, all of which made up Berlusconi's center-right coalition from 2001 to 2006. First was Berlusconi's own party, Forza Italia (FI), generally representative of business interests. Second was Gianfranco Fini's post-fascist Alleanza Nazionale (AN) party. Third was the regionalist and populist Lega Nord (LN) headed by Umberto Bossi. The last relevant actor includes the remnants of the once powerful Christian democrats, the Centro Cristiano DemocraticoCristiani Democratici Uniti (Ccd-Cdu) which later formed the Unione dei Democratici Cristiani (UDC) (Geddes 2008).

These parties adopted xenophobic rhetoric mirroring the anti-immigrant sentiments of their respective bases. For example, in the 2008 general elections, the center-right's xenophobic mantra manifested itself symbolically; single visible minority received the backing of the largest center-right party, Berlusconi's Popolo della Libertà (PDL) ${ }^{2}$. In another incident, the right-wing regionalist LN party joined with protesters opposing the granting of land for the construction of a mosque near Milan by threatening to cover the area with pig manure (Saint-Blancat and Schmidt di Friedberg 2005). What is more noteworthy, however, is that such rhetoric seldom was transformed into policy. Consider the 2001 Bossi-Fini Act, a significant immigration reform bill pioneered by LN leader Umberto Bossi and FI leader Gianfranco Fini. The Act exemplifies that although far-right parties in center-right coalitions, such as the LN, are often the

$2 \quad$ Statistic gathered from the Ministero dell'Interno (Ministry of the Interior) website: http://politiche.interno.it/ ind_poli.htm 
catalysts of immigration reform, the resulting policies have largely maintained a social-welfare net for immigrants (Zincone 2006a). The Act resulted in the greatest case of regularization in modern Italian history, granting amnesty to some 634,728 illegal immigrants (Zincone 2006a). This case of right-wing parties endorsing repressive party platforms yet adopting centrist immigration and visible minority policies is referred to in this paper as a rhetoric-policy divide.

A few relevant examples of the rhetoric-policy divide are henceforth provided. After the passage of the Bossi-Fini Act, The LN's Maroni, acting as Welfare Minister, approved generous immigration rates, including 159,000 in 2005, the highest level in Italian history (Zincone 2006a). The largest growth in legal immigrant population in Italy occurred between 2001 and 2006, when some 1.37 million immigrants entered Italy (Geddes 2008). Maroni even proposed abolishing the quota system altogether in 2003, although the proposal proved too solidarist even for moderates in the government, and subsequently never materialized into policy (Zincone 2006a). Another striking case of a moderate policy is that of AN leader Gianfranco Fini, who in October of 2003 as Deputy Prime Minister introduced a bill granting immigrants the right to vote in local elections, reversing his prior opposition to such a practice (Zincone 2006a).

In this paper, I forward a theoretical framework linking the center-right's immigration rhetoric-policy divide with the Italian culture of political patronage, two topics which, to the author's knowledge, have never been analyzed in tandem. I extend the selectorate theory to show how Italian centerright politicians use political patronage to compensate for moderate immigration policy adoption. I then argue that xenophobic voters face a collective action problem when voting for their center-right representative. Finally, I use multidimensional spatial representations to model the theoretical arguments developed in the paper and draw additional inferences. This political patronage approach is preferable over alternative theories because it can be generalized to explain other issue-driven rhetoric-policy divides in Italian politics.
THE IMPETUS FOR CENTER-RIGHT PARTY MODERATION

The academic literature provides several possible motives for center-right party moderation. One prevalent argument offered in the political literature deals with interest group politics; the preferences of centrist interest groups, specifically solidarist Catholics and functionalist employers, are responsible for the moderate policies adopted by center-right coalitions. Caponio (2005) argues that pro-immigrant groups could rely on Catholic organizations for lobbying support. Zincone (2006a) suggests that the Catholic bloc is reinforced by the support of functionalist employers' organizations who favor the inflow of cheap labor. Because Catholics and businesses make up a significant section of the center-right base, the effect of their preferences on center-right immigration policy cannot be discounted.

A secondary explanation for moderate center-right immigration policy adoption is that center-right political actors are more informed with respect to the immigration issue. There is little evidence supporting a direct correlation between heightened immigration levels and rising crime rates or negative economic consequences. Data from the OECD and Istat show that although immigration rates have steadily increased in the past decade, yearly unemployment has actually decreased with time. Further, yearly real GDP growth rate has been relatively constant in spite of rising immigration levels. Finally, Bianchi et al. (2008:12) find that "total criminal offenses as well as most types of crime are not related to the size of immigrant population once endogeneity is taken into account." This information is likely to be readily available to policymakers, whereas the public is more likely to not be aware of such statistics.

A further possible explanation for why the center-right may wish to adopt moderate immigration policies is that center-right parties are responding to the increased diversification of Italian society. According to the OECD, the number of immigrants in Italy has risen from 1.5 million in 1995 to 5 million in 2006. Center-right parties aware of the dynamic nature of their electoral base may 
therefore be seen as using policy as an appeal to the future electorate and using xenophobic rhetoric as an appeal to the present electorate.

Clearly, there exist a myriad of possible motives for center-right immigration policy moderation. Therefore, treat this condition as a given; Italian center-right parties want to achieve moderate center-right policies. However, academic analyses of how center-right actors are able to achieve this moderation are largely unsatisfactory. For this reason, I shift the focus from why center-right parties wish to achieve moderate immigration policies to how they are able to do so. I argue that the comparatively high levels of political patronage in Italy grant political actors a mechanism to reverse their stated positions on immigration issues and adopt moderate policies.

\section{POLITICAL PATRONAGE IN ITALY AND THE SELEC-} TORATE THEORY APPLICATION

Ever since the 1948 creation of a parliamentary democratic republic, Italian politics has been plagued by unusually high levels of corruption and political patronage (Golden 2000, Golden 2003, Golden and Picci 2005). In fact, in 2000 Italy ranked as the most corrupt 'wealthy democracy', and had levels of corruption more reminiscent of underdeveloped countries like Uruguay than developed European states like Germany (Golden and Picci 2005). Rizzi and Stella (2007) estimate that up to 700,000 Italians are supported or otherwise make their living off of the Italian political patronage system. Although some decrease in political patronage occurred after a significant anti-corruption campaign in the early 1990s named Mani Pulite (Clean Hands), the culture of political patronage clearly remains in present-day Italy (De Monte and Papagni 2007).

The system of political patronage can be formalized through the selectorate theory developed by Bueno de Mesquita et al. (1999), Bueno de Mesquita et al. (2003), and Bueno de Mesquita et al. (2008). The selectorate theory assumes that in a state with $N$ citizens, a subset of those citizens, $S$, known as the selectorate, actually plays a role in determining whether or not an actor remains in office. A further subset of the selectorate, $W$, makes up the winning coalition, or the number of supporters needed for an actor to remain in power. In order to stay in office (which Bueno de Mesquita et al. (1999) define as the universal motivator of all political actors), actors consider the size of their $W$. When faced with a large $W$, policymakers are likely to attempt to gain the group's support through the diffusion of public goods (Evans et al. (1993)), (Bueno de Mesquita et al. (2008)). The non-excludability of the public good means that a member of an actor's $W$ can leave the coalition and still reap the benefits of the public good (Bueno de Mesquita et al. (2008)). This means that it is relatively easy for people to leave a $W$ if they are not pleased with the actor. Conversely, a policymaker facing a smaller $W$ will shift focus to key individual players, and the distribution of private goods becomes a more effective means to assemble a $W$ (Bueno de Mesquita et al. (2008)). Because private goods are excludable from others, each individual in the $\mathrm{W}$ benefits more than members of the selectorate. Therefore, members of an actor's $W$ will be less likely to defect because they will lose access to private goods, ensuring the politician's re-election bid (Bueno de Mesquita et al. (2008)).

The selectorate theory offers answers to the center-right immigration dilemma. Center-right actors can keep their electoral base relatively satiated through the distribution of private goods. Because of the high saliency of immigration issues for the voter base of the center-right, private good diffusion is likely to be more significantly used, rendering political patronage more widespread. Further, because of the prevalence of political patronage, the expected political (or legal) cost of engaging in such practices is not high (Del Monte and Papagni 2007).

THE EFFECT OF POLITICAL PATRONAGE ON VOTER BEHAVIOR

Political actors would not diffuse private goods if they did not seek to affect voter behavior and enhance their re-election bids. I argue that the political patronage system is used by political actors to cause a systematic mass deviation in the 
payoffs (and therefore, the voting preferences) of the electorate.

First, voters may not be as aware of the policies endorsed by a specific politician but they are likely aware of their personal benefits incurred from private good diffusion; this creates a problem of asymmetric information. Another significant consideration that makes re-election more lucrative to voters is the knowledge of the unfeasibility of cooperation. If the voters of an individual constituency coordinate and oust their MP (Member of Parliament) but all other constituencies re-elect their MP, they no longer benefit from private good diffusion and the rhetoric-policy divide is relatively unaffected. This creates a collective action problem for voters; the benefit is incurred if all manage to coordinate (to oust their MPs), but each player suffers if they coordinate (oust their MP) while the rest defect (re-elect their MPs). Therefore, if people are risk-neutral (or risk averse), they have an incentive not to oust their MP.

This analysis can be represented more formally by depicting a voter's decision regarding whether to 're-elect' or 'oust' as a decision tree, as shown in Figure 1. Suppose that a voter receives a payoff $X-p$ from ousting and a payoff of $k X$ from reelecting, where $0<k<1 . k$ in this case is a measure of the relative decrease in utility caused by the MP adopting moderate immigration policies, and $p$ is the decrease in utility to the voter caused by asymmetric information and the knowledge of a collective action problem. In this case, if $k>1-(p / X)$, then $\mathrm{P}_{\mathrm{o}}<\mathrm{P}_{\mathrm{r}}$, where $\mathrm{P}_{\mathrm{o}}$ is the payoff from ousting and $\mathrm{P}_{\mathrm{r}}$ is the payoff from re-electing. I argue for the likelihood that, from 2001 through 2006, xenophobic voters received higher payoffs from re-electing than ousting, meaning that the reduction in payoff caused by $p$ was greater than the reduction in payoff due to $k$. This ensured the continued re-election of politicians who were able to continue to adopt moderate immigration policies.

\section{SPATIAL REPRESENTATIONS}

So far, I have not provided an explicit reason why MPs would choose not to also moderate their rhetoric. The answer to this question, along with further support of the conclusions of the political patronage approach, can be derived through spatial representations which draw loosely from the veto player framework of Tsebelis (2002).

We begin by first representing the preferences of voters and MPs on a spectrum. Estimated policy and rhetoric preferences of voters and MPs are shown in Figure 2. The ideal point of the median voter is $v$ and the ideal point of the median center-right actor is MP. The median voter's reservation point, or the point leaving the voter indifferent between re-electing and ousting the politician, is rp. We can derive that all points which are the same distance away from $v$ as rp are also reservation points, and this is displayed through the indifference curve which passes through rp (labeled ic). An MP facing an electorate with the preferences noted in Figure 2 can adopt any position which lies along or inside the ic, but not outside of it without being ousted from office.

Now we can turn to a comparative statics analysis to assess the effects of private good diffusion. Ceteris paribus, private good diffusion renders voters more accepting of positions which differ from their own. The result is that the reservation point becomes more solidarist, and the indifference curve shifts outward. This means that, after private good diffusion, the MP is able to adopt a position closer to his own ideal point while still maintaining the support of the voters. This is shown in Figure 3: before private good diffusion, the MP had to adopt position $\mathrm{p}$, whereas after private good diffusion, the MP could adopt a more solidarist policy position, p'.

A question remains, however: why would center-right political actors mirror the preferences of the electorate on the rhetoric dimension? Consider Figure 4; there are three MPs represented who all have the same ideal policy stance but differing ideal rhetoric stances. $\mathrm{MP}_{3}$, who mirrors the preferences of the electorate, is able to adopt a position $\left(\mathrm{p}_{3}\right)$ which is more solidarist than either $\mathrm{MP}_{2}$ or $\mathrm{MP}_{1}$. Even without private good diffusion, center-right MPs seeking to adopt moderate immigration policies should mirror the rhetoric of the electorate. Thus, ceteris paribus, mirroring the electorate's rhetoric allows the MP to adopt more solidarist policies. 
Further, are there any possible rhetoric positions which the MP can adopt in order to adopt policy preferences which, on the policy dimension, lay past the voter's reservation point? Indeed, a graphical analysis does show that this is possible in multiple dimensions. Consider Figure 5. If one draws a horizontal line along the voter's policy reservation point, we can derive a region (the shaded triangle) delineating where an MP is able to adopt rhetoric positions which lie below the voter's policy rp. In essence, if ( $v M P$ ) lies within the shaded triangle and the MP's ideal point lies outside the voter's indifference curve, then the MP will adopt a policy which lies below the voter's policy rp.

\section{CONCLUSIONS}

To recapitulate, a multidimensional spatial analysis supports the conclusions of the political patronage approach. Center-right political actors can adopt moderate or solidarist immigration policies while retaining the support of xenophobic center-right voters. This can be achieved in two ways; through private good diffusion, which shifts out the indifference curves of voters, and through the adoption of xenophobic rhetoric which mirrors the preferences of the electorate. This conclusion is shown in Figure 6.

Overall, I seek to provide an alternative approach, as summarized in Figure 7, to the study of immigration and center-right parties in Italy. The important contribution of the political patronage approach is in its analysis of the center-right's immigration rhetoric-policy divide in tandem with the Italian political patronage system. While political patronage and the positions which center-right politicians adopt may seem unrelated at first glance, I argue that political patronage is the primary reason why the rhetoric-policy divide can exist. Further, despite the apparent peculiarity of the Italian center-right's rhetoric-policy divide on immigration issues, I suggest that it can be described using simple game-theoretic tools. In so doing, I argue that the center-right's rhetoric-policy divide on immigration issues is not a unique aberration, but rather a predictable product of rational choice behavior and a suitable system of political patronage.

\section{ACKNOWLEDGEMENTS}

I would like to thank political science Professor Kenneth Kollman and Ph.D. candidates Jennifer Miller and Cassandra Gafström for helpful comments and resource provision. Their support was invaluable to the development of this paper. All errors in this paper are my own.

\section{REFERENCES}

1. Bianchi, Milo, Buonanno, Paolo, and Paolo Pinotti. 2008. "Working Paper 698: Immigration and Crime: An Empirical Analysis." In Working Papers from Banca D'Italia (December 2008). Accessed December 6th, $2009<$ http://www.ristretti. it/commenti/2009/gennaio/pdf3/immigrazione_crimine. pdf $>$.

2. Bueno de Mesquita, Bruce, Alastair Smith, Randolph M. Siverson and James D. Morrow.1999. "An Institutional Explanation of the Democratic Peace." American Political Science Review 93: 791-807.

3. Bueno de Mesquita, Bruce, Alastair Smith, Randolph M. Siverson and James D. Morrow. 2003. The Logic of Political Survival. Cambridge, MA: MIT Press.

4. Bueno de Mesquita, Bruce, James D. Morrow, Randolph M. Siverson and Alastair Smith. 2008. "Retesting Selectorate Theory: Separating the Effects of W from Other Elements of Democracy." American Political Science Review 102(12):393400.

5. Caponio, Tiziana. 2005. "Policy Networks and Immigrants' Associations in Italy: The Cases of Milan, Bologna, and Naples." Journal of Ethnic and Migration Studies 31(5): 931-950.

6. Del Monte, Alfredo, and Erasmo Papagni. 2007. "The Determinants of Corruption in Italy: Regional Panel Data Analysis." European Journal of Political Economy 23 (2): 379-396.

7. Evans, Peter B., Harold K. Jacobson and Robert D. Putnam. 1993. Double-Edged Diplomacy: International Bargaining and Domestic Politics. London, England: University of California Press.

8. Geddes, Andrew. 2008. "Il Rombo dei Cannoni ? Immigration and the Centre-Right in Italy."Journal of European Public Policy 15(3): 349-366.

9. Golden, Miriam A. 2000. "Political Patronage, Bureaucracy, and Corruption in Postwar Italy."Prepared for the annual meeting of the American Political Science Association. University of California, Los Angeles.

10. Golden, Miriam A. 2003. "Electoral Conncections: The Effects of the Personal Vote on Political Patronage, Bureaucracy, and Legislation in Postwar Italy." British Journal of Political Science 33(2): 189-212.

11. Golden, M. and Lucio Picci. 2005. "Corruption and the Management of Public Works in Italy." in S. Rose-Ackerman (ed.), Handbook of Economic Corruption, Cheltenham: Ed- 
ward Elgar.

12. Rizzo, Sergio, and Gian Antonio Stella. 2007. La Casta: Così i politici italiani sono diventati intoccabili. Milan, Italy: Rizzoli.

13. Saint-Blancat, C. and O Schmidt di Friedberg. 2005 "Why are Mosques a Problem? Local Politics and Fear of Islam in Northern Italy." Journal of Ethnic and Migration Studies 31(6): 1083-104.

14. Tsebelis, George. 2002. Veto Players: How Political Institutions Work. Princeton, NJ: Princeton University Press.

15. Zincone, Giovanna. 2006a. "The Making of Policies: Immigration and Immigrants in Italy."Journal of Ethnic and Migration Studies 32(3): 347-375.

\section{APPENDIX}

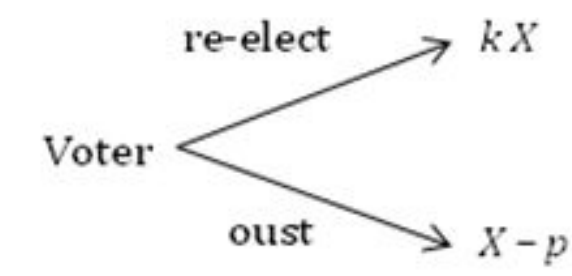

Figure 1)

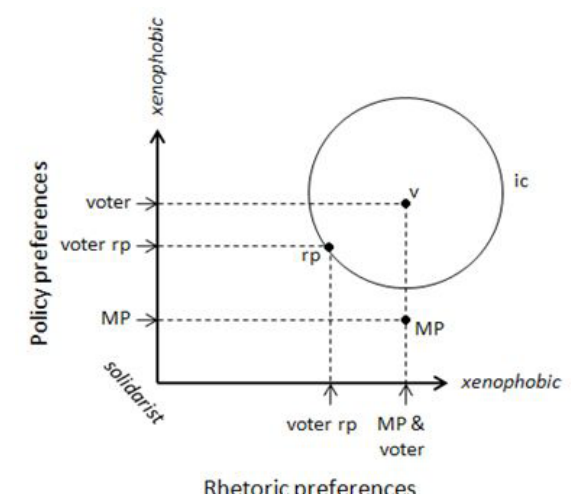

Figure 2)

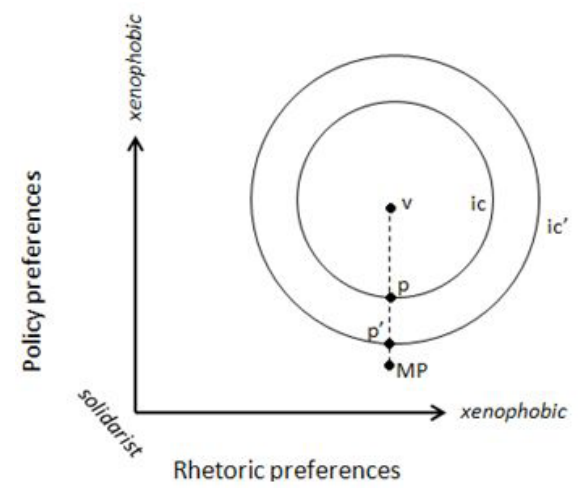

Figure 3)

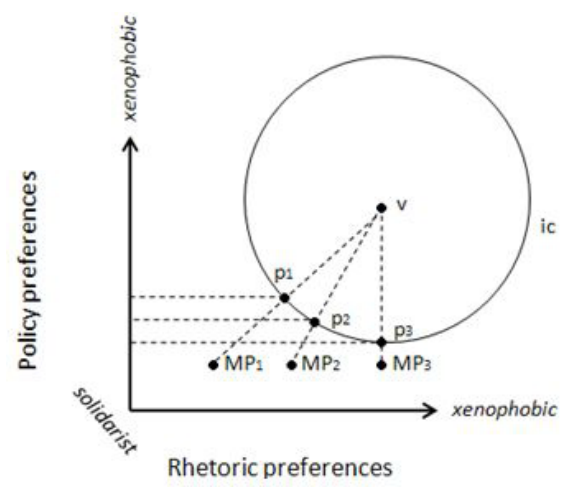

Figure 4)

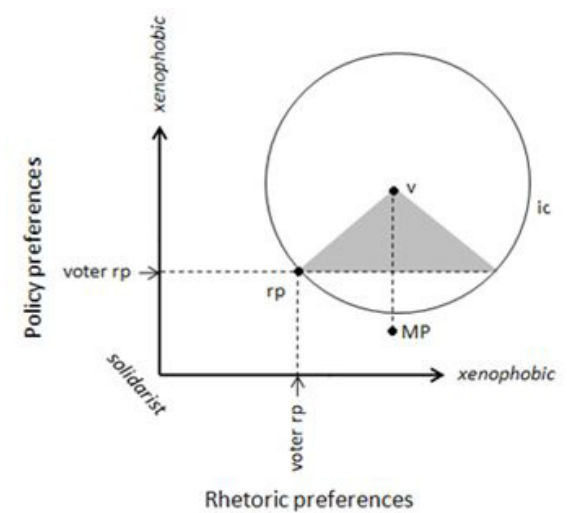

Figure 5)

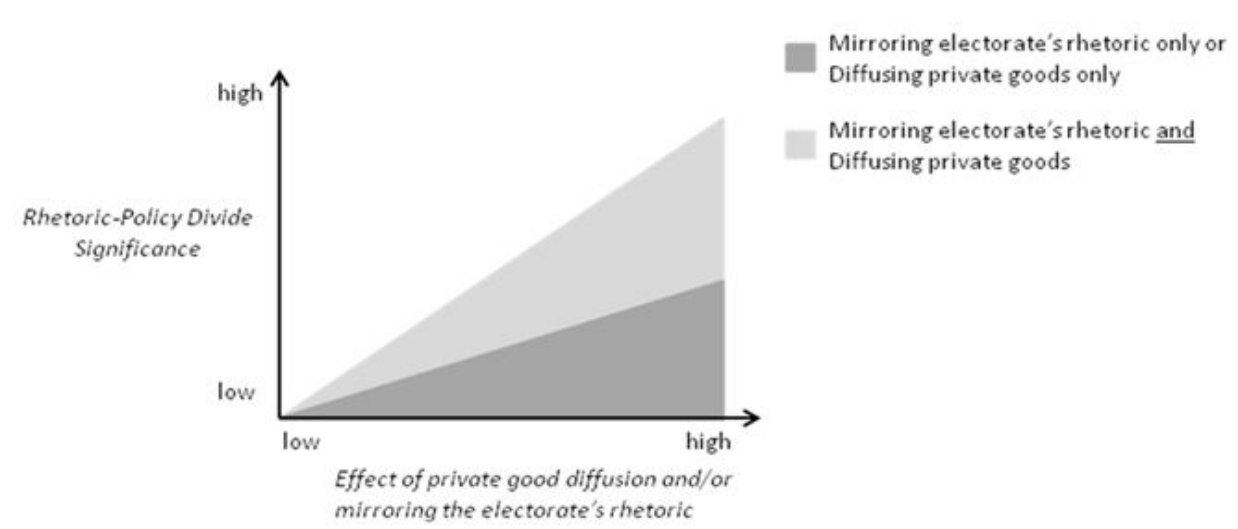

Figure 6)

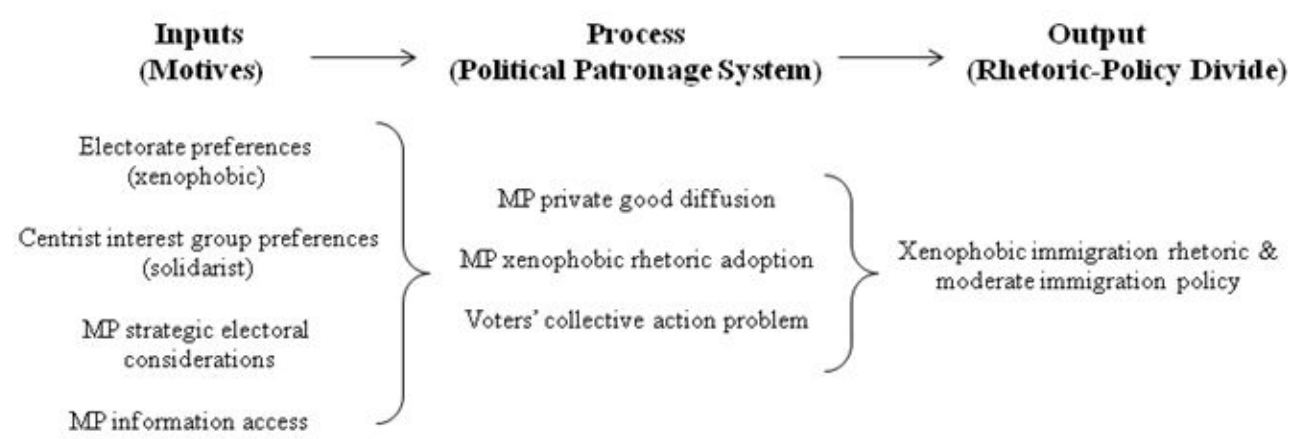

Figure 7) 